\title{
Preaching to effect change
}

\author{
Judith M McDaniel (Virginia Theological Seminary) ${ }^{1}$ \\ Research Associate: Department of Practical Theology \\ University of Pretoria
}

\begin{abstract}
This article begins with a theological argument, then proceeds to practical application. Its thesis is that there is an inherent link between the character of the preacher, the character of the congregation, and the character of the gospel proclaimed. They mirror one another. Many congregations are not equipped to deal with change, growth, or evangelism because they have become entrenched in one style of leadership or structured life; thus, before congregations can change, before a congregation can take a new direction in gospel living, the character of the preacher must be converted. This contribution to the topic proposes that the character of the preacher and the preacher's congregation can draw closer to the character of the gospel through the practice and teaching of homiletics.
\end{abstract}

\section{INTRODUCTION}

In the second chapter of Acts ( $v 17$ ), Peter preaches his first sermon and quotes from the prophet Joel (2:28): "In the last days it will be, God declares, that I will pour out my Spirit upon all flesh, and your sons and your daughters shall prophesy, and your young men shall see visions, and your old men shall dream dreams ... ." He is preaching to what might be called an interim congregation, one in which the Messianic age has begun but has not yet reached its fulfillment. God's Spirit has descended, but the Day of the Lord, the end of time marked by judgment and blessing, has not yet arrived.

In a sense, all congregations since the first century of the Common Era have lived in an interim period, a kairos time, a high time, a period of intense quality, an opportunity for listening, watching, and envisioning, a time and space for forming thoughts and forming selves. As Paul put it (Rm 8:23), we have received the "first fruits," but we groan inwardly as we wait for adoption.

\footnotetext{
${ }^{1}$ The Rev Dr Judith M McDaniel is the Howard Chandler Robbins Professor of Homiletics at the Virginia Theological Seminary and a research associate of Prof Dr C J A Vos, Dean of the Faculty of Theology at the University of Pretoria.
} 
In the mean time, we live in the interim between the already and the not yet of the Kingdom; and in that interim period the church needs leadership.

How is leadership exercised from the pulpit and how is change effected? In this regard there can be no question that there is a constellation of power around the pulpit. Does that power belong only to the designated leader, the one chosen by the people; or can others besides the perceived leader influence congregational development from the pulpit? Put another way, does the power of the pulpit arise simply from the fact that the one speaking - whether lay or ordained - has been authorized to give voice to the practices of the Christian faith? To say that speaking for the faith from the location of the pulpit is somehow different from witnessing elsewhere implies that there is an iconic nature within preaching itself. Unlike a speech delivered before an assembly, "preaching constitutes the church" (Pelican \& Lehman 1986:73). In other words, at least part of the iconic nature of preaching is its capacity to create identity.

Preaching advances the understanding of faith, affects faith development. But for the individual who does the preaching to effect faith development requires the capacity on the part of the preacher to see visions and dream dreams. Whether functioning as the interim pastor for a congregation in transition or as the senior minister in a long-term pastorate, the effective preacher discovers what the dreams of the congregation are and preaches to those dreams. Such a statement does not mean that the interpreter of dreams is a topical preacher, basing his or her vision on limited and flawed human experience. Neither does he or she tell the people what they should dream. Rather, the interpretive preacher goes with the eyes of the congregation to the Scripture to study all the aspects of the readings for the day and brings them to bear on the congregation's dreams. The congregation expects their preacher to be the rabbi, the one who knows and shares the history, the knowledge, the accumulated wisdom about the scriptural passages and ushers that good news into the present.

Knowing that there are developmental tasks to be facilitated in the creation of identity, the interpreter of dreams speaks to the theological bases of those tasks, the warrant, the deeper demand of those tasks so that those bases can, in turn, be related to the congregation's dreams. For example, "Why is ecumenical dialogue, reconnecting with other Christians, important?" some members of a congregation might ask. The theological basis of that reconnection is grounded in community, the need of all believers to be in communion with one another, mirroring the nature of God in three persons Father, Son, and Holy Spirit in eternal communion. The Trinity is the model for all human community. God's three Persons acted in communion in creation; 
and therefore, all humans are created by God to be in communion with one another. The ideal of reconnecting is to model life on Trinitarian love, for the mission of the church is to bring about unity for the whole human race. This way the church becomes a model of koinonia ecclesiology, a model of life shared within the Trinity. When the church shares and lives that model, it becomes an agent of love for the whole world. This sort of witness enables us to live in community with those with whom we differ on issues, influencing others to love one another even when we disagree.

A preacher can influence people if only because preaching changes their experience. But note: We change their experience. They themselves change their minds. Speaking good news can make change happen because words can name God at work in the world, and that naming is power. But preachers need to be wary: We need to be transparent in the pulpit. We want to represent Someone else, not ourselves. And when we leave, we don't want the church to collapse because a personality cult, dependent on our leadership, has developed.

Naming God at work in the world requires balance, but the Bible is a vehicle for standing with one foot in this world and the other foot in the next. As we read and interpret the Bible, we are vulnerable, vulnerable to the Bible's capacity to author identity and values in those who listen to its words and the words of carefully exegeted sermons. Such vulnerability creates the capacity to see visions and dream dreams, to understand and act in new ways as God's people in the interim between the already and the not yet.

\section{PREACHING IN THE INTERIM}

Moving people is one of the three tasks of every sermon, according to Augustine in the first preaching textbook, De Doctrina Christiana. He "baptized" Cicero's three tasks of every sermon - to instruct, to delight, and to move - by interpreting "move" to mean creating the capacity to take ethical action. So how do we encourage the capacity to take ethical action?

Aristotle wrote that appropriate arguments to effect change include ethos, pathos, and logos in that order. If ethos, the character of the speaker, has more effect on the listener than either the emotion aroused in the listener or the content of the words spoken, then the cultivation of character, the ministry of presence or ethos, is part of the vocation of Christian leaders; and there are as many media for the exploration of character as there are definitions of ethos. But our purpose here is not to define ethos. Definition, like explanation, is too limiting. Description is a better medium for discovery and development. Description allows us to paint a picture in our minds of the life 
we want to form, of the character for which we will strive as Christian leaders and preachers.

"Character is fate," stated the sixth century BCE Greek philosopher Heraclitus. "Character is fate." Christians might accede, but only up to a point. We would agree that the learning we acquire, the choices we make, the virtues we strive to emulate dictate the shape our life assumes. We might agree that character is determinative of the direction one's life takes but would add a caveat. Christians would say character is something more than irrevocable destiny. Christians claim that God is both creator and final arbiter of character's telos or goal, that God is both the divine source and the end of life's meaning. Because we have freedom, we sketch the form and choose the colors of our character, but God is the artist who provides the tubes of paint and brushes that implement our work, then frames our final destination.

Such a statement is not meant to imply that God is separate from character formation in the midst of life. From time to time, in those proskairos moments we call "grace", God passes by. God crosses the boundary from transcendence to immanence. From time to time God tints the canvas; and if we perceive that revelation, life's direction is changed. But much of the time we are the painters, schooling ourselves to recognize grace when grace occurs, searching for insight, working hard at formation, ours and the congregation's. Or as Norman Maclean would say, "All good things - trout as well as eternal salvation - come by grace and grace comes by art and art does not come easy" (Maclean 1976:4).

This formed life, this work of art we are sketching for ourselves and our congregations, cannot be achieved through a simple "paint by numbers set." The numbers we need are infinite. But one thing we know for sure: Some of the colors chosen from our palette are, by virtue of the human condition, dark. An episode from the story of Elijah is one such color.

Elijah has fled to Horeb, to the cleft in the rock of the mountain in which, tradition tells us, a similarly disheartened Moses (Ex 33:12-23) had previously sought to discern the manner of God's action in the world. But Elijah is not so much seeking the glory of God as he is venting his own frustration. Elijah is focused on fear and consumed with complaint. He claims to be zealous for the Lord; but he has lost his direction. He wants to make his own choices, to serve his own needs. He wants to sketch a different scenario than the life he has been leading. He wants out. What's wrong with this picture? We soon discover: Elijah is not listening. The issue is not the presence or absence of God. The problem is Elijah's spiritual individualism and pride. Elijah's character has a tragic flaw: egoism. Elijah has "(arrogated) 
to himself the power that is properly (God's)" (Walsh 1996:282). In primary colors we see the clash of human will and divine will.

How quickly both Elijah and we learn to serve our own needs. How quickly God's ministry becomes my ministry serving my own designs; or, speaking as a congregation, "We've always done it this way." Here is idolatry of a different sort from the worship Elijah has just confronted in the priests of Baal, but idolatry all the same. Too soon ministry becomes equated with what one knows and does rather than who and whose one is. The clash of Elijah's will and God's will reminds us that God makes demands of Christian identity, and God will not be mocked.

As in other theophanies (Ex 19:16; 20:18; Dt 4:11; 5:24; Jdg 5:5; Job 38ff; Pss 18:12-14; 68:8; Is 30:27 and Nah 1:3b; 1:5) wind, earthquake, and fire portend the approach of God; but in this case, something more confounding heralds God's approach: the sound of sheer silence. By means of ineffable paradox God gets Elijah's attention. Only then, in silence, is Elijah aware that God has passed by. Only when he is overtaken by the awe and majesty of silence does Elijah know that God has passed the boundary from transcendence to immanence, that God is breaching the barrier erected between human will and God's will. The silence is not the point, for God is not in the silence. Silence is only a harbinger, an indication of the approach of God. Listening, expectant listening, is the point.

Is this silence that heralds the coming of God what Ignatius of Antioch had in mind when he wrote to the church in Magnesia (8:2), " $\ldots$ there is one God who revealed himself through Jesus Christ his Son, who is his Word which proceeded from silence ..."? Certainly the silence of God emphasizes God's transcendence in Ignatius' theology. God is utterly other in sovereignty and judgment, his silence indicating hidden purposes in the unfolding of the divine plan. But it is of the essence of God to be in relationship, the nature of God to take the initiative in search of relationship; to reveal Himself as the source of life itself; to pursue us. It is of the essence of God to עבר, to pass the boundary. As Ignatius' letter implies, the Word was and is present at creation and in revelation, drawing near by grace. What remains for Elijah and for us is to be still and know that God is God. Be still, not be passive, but desist. Desist from the pursuit of our own needs, our own projections, the selffocused goals for "my" ministry and the congregation's ministry, and listen for the Word to pass by. Listen ... for the future to break into the present. 
"I said to my soul, be still," wrote the poet T S Eliot,

I said to my soul, be still, and wait without hope

For hope would be hope for the wrong thing; wait without love

For love would be love of the wrong thing; there is yet faith

But the faith and the love and the hope are all in the waiting.

(Elliot 1971:28)

Listen and wait. Watch for God to draw near. If you and I had witnessed this tableau, had climbed Horeb to the cleft in the rock, what would we have seen? Would we have recognized God in our midst? Faced with threats of war and terrorism, shocked by the tragic loss of life in Israel, Iraq, Afghanistan, are we prepared for something or Someone who is Other than anything we expect? How does one shape one's own character or the character of a congregation so as to be ready for God to pass by, ready to listen expectantly for the Word of revelation, ready to listen dreams into existence?

The psalmist (Ps 130) tells us something of how he prepares for God to pass by. He writes, "My soul waits for the Lord, more than watchmen for the morning, more than watchmen for the morning." "Out of the depths," as Psalm 130 is often named, "out of the depths" is the poetry of individual lament. But lament is always voiced with the expectation of satisfaction. Lament is uttered with the confidence that God will penetrate the boundary between height and depth, between absence and presence, between transcendence and immanence. And the human vessel for that penetration is the watchman, the interpreter of dreams.

In the tradition of many cultures there appears the theme of a watchman. Six centuries before the Common Era, the watchman on the Ishtar Gates of Babylon witnessed the conqueror of the known world, Cyrus, King of Persia, enter the city. You and I can see these massive sapphire blue gates adorned with mythic creatures today, in the Pergamum Museum in East Berlin. Cyrus is the only non-Israelite in the Old Testament to whom the title "messiah" is given. Unaware of his charge from God, Cyrus is depicted in Scripture as the agent of the Lord, an enlightened ruler who returns the spoils of war and permits the conquered exiles to return to Jerusalem and restore the decimated temple. But while the Persians gained much by their contacts with other civilizations, there is no evidence that Cyrus ever acknowledged the sovereignty of God. There is no evidence that he recognized God in the midst of life. And the Persian Wars with Greece ended in disaster for the house of Cyrus. 
A century after Cyrus as the returned exiles were rebuilding the temple, the victorious Greeks performed their own religious ritual at home, Greek theater. For that theater, Aeschylus wrote the trilogy Oresteia. The first book of Orestia, the Agamemnon, opens with another watchman, another witness to war and conquest, the fall of Troy. You and I can read Agamemnon today and experience not the physical but the poetic/psychological reality of ancient Greece. We can experience once again a witness not to God but to the tragic flaws of human hubris and necessity.

A contemporary of Aeschylus, the author of Psalm 130, like a watchman stands ready within the temple precinct of Jerusalem. But the psalmist is not looking for conquerors or for signs of war. He looks for a different kind of deliverance. This poet looks for both his own and Israel's consolation. He looks for the fulfillment of hope. This artist waits to witness a vision of wholeness because he has been prepared to see that image. He has been schooled to see. How was the psalmist prepared, one might ask.

"My soul waits for the Lord, more than watchmen for the morning, more than watchmen for the morning" (Ps 130:5), he writes. The psalmist's preparation - his seminary experience, if you will - has been the words of his faith tradition, such songs, prayers and promises as those found in Isaiah, "my eyes have seen your salvation (Is 40:5), which you have prepared in the presence of all peoples, a light for revelation to the Gentiles and for glory to your people Israel" (Is 49:6). The psalmist's entire reality is shaped by the images of faith. So he comes to the city where poetry and history meet. He comes to the city where earth and heaven meet, a city you and I can see, a city you and I can know. He comes to Jerusalem.

The southern steps of the temple precinct, physical steps that are there still, are steps you and I can climb today up the southern slope of the Old City walls. Approaching the eleven-acre temple precinct, we see the Hulda gates, physical gates still evident though they have been sealed shut since the seventh century. To the right as we approach the Hulda gates is the southeast corner of the outer court of the temple precinct. This corner is called the pinnacle of the temple, not because it is the apex of the temple itself but because it looms high above the Kidron Valley, high enough to be the perfect spot for a watchman.

At one archeological level, Jerusalem is composed of geology: valleys, hills, springs of water. Upon that level is built biblical history: fortress walls, symbolically named gates, steps of the temple. Atop both those levels is Jerusalem's spiritual stratum: a city of memory, hope, and integration. Physical geology, biblical history, and faith. All three understandings are 
needed in order to comprehend the simple yet complex statement "My soul waits for the Lord, more than watchmen for the morning."

In the Middle Ages, Christian preachers added four layers of interpretation to the three we inherited from our Hebrew forefathers and mothers in the faith. At the literal level, Jerusalem is a city of Judea. At the allegorical level, Jerusalem represents the church. At the mystical level, Jerusalem is the city of God. At the moral level, Jerusalem symbolizes the soul of the human being.

In the eighteenth century, the poet William Blake ${ }^{2}$ gave the name "Jerusalem" to all that is tender in the human soul. He wrote, "I give you the end of a golden string. Only wind it into a ball. It will lead you in at Heaven's gate, Built in Jerusalem's wall." Blake's poetry suggests that the route to the tenderness of the human soul is something like a labyrinth we follow through life. The end of the golden string is the grace given to each of us which can too easily become "hidden under the circumstances of our daily life (or even) lost if we choose not to attend to it" (Barnhart 2001/02).

Now in the twenty-first century, we add our own level of interpretation. Judging from the frequency with which we hear about the search for deeper spiritual understanding, it would appear that increasing numbers of people are seeking to attend to the holy image in their lives and their role in relationship to it. But are they attentive to grace and to the soul? No, most don't negotiate that turn. The therapeutic model is much more accessible, and that model is rampant in our culture. Just go to your neighborhood newsstand or local bookstore and browse the aisles on self-improvement. True, some of these authors invoke a higher power, but that appeal is only for the purpose of selfhelp; and self-help is hardly the answer to hubris or human tragedy. Those whose answer is self-help follow not so much a labyrinth as a beltway that circles round and round but never enters in.

I am reminded of a Peanuts example of living as if avoiding the turn to the soul: Lucy is parked in her psychiatric booth, and Charlie Brown is sharing his problems with her. "Sometimes I ask myself questions," he begins.

"Sometimes I ask myself, 'Is this your real life, or is this just a pilot film? Is my life a thirty-nine-week series or is it something special?"' In no time at all Lucy analyzes his problem and gives an instant answer: "Whatever it is, your ratings are down. Five cents, please!"

There are no rehearsals before the opening performance of our lives. There are no pilot episodes or reruns, though some of us practice the labyrinth of faith - listening, watching, envisioning - as if we were opening in

\footnotetext{
${ }^{2}$ I am indebted to Henry Carse, instructor at St George's, Jerusalem, for pointing out the connection between medieval hermeneutics and Blake's poem.
} 
Philadelphia before subjecting our show to the bright lights of Broadway! We live as if rehearsing for life because we're unwilling to go deep enough.

If we really believed God were, as God is, our ultimate audience, would our ratings be down? Churches don't have to become museums, or mausoleums. We have the images this world desperately needs to shape its life. Wall Street doesn't have them. Madison Avenue doesn't have them. Much of television doesn't have them. We have them. We have the good news of God with us, God for us every day to share with our congregations and with the world. Then why aren't we better at recognizing God in the midst of life?

Perhaps we fail to see because we aren't persistent enough about seeking spiritual nourishment. We aren't persistent enough about winding that golden string. You may remember the priest who announced during Sunday morning worship that in the interest of time - which was running short - the congregation would only sing one verse of "Take Time to be Holy." Yes, it takes time to be holy. It takes time to set aside regular routines for worship. It takes time to prepare ourselves to find God in the midst of life by reading words of Scripture, meditating upon the psalms, watching for the promises. It takes a lifetime. But God is passing by, crossing the boundary between transcendence and immanence even now, bestowing grace upon grace. We can listen for God today. We can watch for God today. We can see God in the midst of life.

But nourishment dare not stop. Twenty, fifteen, even ten years from now, will you and I have preached or taught ourselves dry? Or will character formation - discovery and development - continue throughout our ministries? It has been said that the religious person thinks life is about taking some kind of journey. The non-religious person thinks there is no journey to take. In Luke the word for journey is "exodus". You and I are on an exodus away from lesser images of life. You and I are on a journey towards God. The only question is whether we will listen and watch or if we will allow grace to be hidden under the circumstances of our daily lives.

We each have been and are being given the end of a golden string. That string leads to Heaven's gate, built into the wall of the city where faith and life negotiate. At the intersection of physical geology, biblical history, memory and hope, we together with the psalmist wait. We with the psalmist stand negotiating between life and faith, but deep in his soul the psalmist is expecting to meet God. Do you and I live with that same sense of expectation?

We have said that listening and watching are elements in Christian preaching and the formation of Christian character, but we have said little about the acquisition of vision. Who are those who call others to account 
when God passes by, and how might we paint their portrait? What are the dimensions of Christian character formation that uniquely combine to make possible the dreaming of dreams and the calling of others to follow those dreams? Does the leader have just the right proportion of listening skill and visionary ability, a charismatic personality; or is he or she less than perfect?

Those preachers who enter into this peculiar process of planting one foot firmly in the Scripture and tradition we have thus far assimilated, poising the other to step out into the unknown where character is all that we have, are treasured, treasured by God. As Frederick Buechner writes, "They are treasured less for who they are and for what the world has made them than for what they have it in them at their best to be, because ultimately, of course, it's not the world that made them at all."

When we are balancing on the boundary between who we are and what we have it in us at our best to be, we begin to live with vision. We live, not "free-styling in the zone", ${ }^{3}$ but steadied by the witness of Scripture, tradition, and the tradition community of which we are a part. Balancing on that boundary, we live equipped to "mediate (God's) absolute presence within a relative world" (Homes III 1976:8). The formation of Christian leaders is for the purpose of mediating transcendence, according to Urban Holmes, mediating those moments of grace when the barrier between heaven and earth is broken.

The vocation of a Christian preacher is to be the mediator of those moments when God passes the boundary between transcendence and immanence. We mediate by leading others to their own discovery of God, forming the whole people of God to envision teleios, to listen and watch for consummation.

The life you and I form as Christian preachers is worked out on the horizons of meaning. The Christian preacher you and I are becoming is our work of art, imagined by you and by me, perfected by God.

The French novelist Emile Zola wrote:

If you ask me what

I can do in this world,

I, an artist, will answer you:

I am here to live out loud.

Always listening, always watching, always envisioning, the life of the Christian preacher is formed to live out loud in witness to God's approach.

${ }^{3}$ Female rap artist Sarai Howard, a k a "Feminen." 


\section{Works consulted}

Barnhart, B 2001/02. The Golden String Newsletter. Bede Griffiths Association.

Eliot, T S 1971. Four quartets. New York: Harcourt, Brace \& World.

Homes, U T III, 1976. Ministry and imagination. New York: Seabury.

Maclean, N 1976. A river runs through it and other stories. Chicago, IL: University of Chicago Press.

Pelican, J \& Lehmann, H T (eds). Luther's Works, American edition, Vol 32. St Louis, MO: Concordia Publishing House.

Walsh, J T 1996. 1 Kings. Collegeville, MN: Liturgical Press. 